\title{
CONDITIONS OF STUDENT'S ACTIVATION IN TECHNICAL EDUCATION
}

\section{Elżbieta MASTALERZ}

\begin{abstract}
Author describes basic issues concerning student's activation goals and purposes of technical education, and correct conduct of technical lessons in schools. Conditions for practical technical activation are formulated basing on literature and research.
\end{abstract}

Key words: activation, student, teacher, technical education.

\section{WARUNKI AKTYWIZACJI UCZNIÓW W EDUKACJI OGÓLNOTECHNICZNEJ}

Streszczenie: Autorka omawia podstawowe zagadnienia z zakresu aktywizacji uczniów, cele i zadania edukacji technicznej oraz niektóre zagadnienia poprawnej realizacji zajęć technicznych na lekcjach $w$ szkołach ogólnokształcacych. W oparciu o literature $i$ badania pedagogiczne formułuje warunki aktywizacji uczniów w działaniu praktyczno - technicznym.

Słowa kluczowe: aktywizacja, uczén, nauczyciel, edukacja ogólnotechniczna.

\section{Wprowadzenie}

Podstawowym celem i zadaniem systemu edukacji ogólnotechnicznej powinno być kształtowanie historycznego i perspektywicznego rozumienia procesu postępu naukowotechnicznego i świadomego korzystania z osiągnięć techniki. Postęp powoduje zmianę sytuacji człowieka w życiu społecznym i cywilizacji współczesnej. Z tych względów pedagogika musi się zająć przygotowaniem młodego pokolenia do realizacji humanistycznego stylu życia i podporządkowania techniki potrzebom ludzkim. Człowiek XXI wieku musi być wdrażany do aktywnego, rozsądnego konsumowania nowoczesnych wytworów i technologii w dziedzinach życia prywatnego, jak też w obszarze wybranego zawodu.

\section{Aktywizacja uczniów}

Aktywizacja w procesie nauczania jest to pobudzanie podmiotu nauczania bodźcami intelektualnymi i emocjonalnymi do myślenia i działania w celu rozwoju osobowości i opanowania materiału programowego. Podobnie jak w poprzednich dziesięcioleciach, tak i obecnie bardzo duży nacisk kładzie się na stymulowanie przez nauczyciela tej aktywności u uczniów, coraz mocniej akcentując pracę, zaangażowanie wszystkich uczestników procesu dydaktycznego. Nauczyciele prześcigają się w stosowaniu różnorodnych metod aktywizujących tak, by uczeń był coraz bardziej zainteresowany i chętny do współpracy, by zajęcia nie były nudne i monotonne. Jednak sama znajomość metod aktywizujących nie wystarczy do zachęcenia ucznia do pracy na lekcjach. W procesie dydaktycznym niezbędne jest zaplanowanie takiego układu zadań dydaktycznych, który pozwoli nauczycielowi wykazać dobrą znajomość nauczanych zagadnień z jednoczesnym wyzwalaniem aktywności poznawczej uczniów i zaangażowaniem w wykonywanie zadań zleconych w danej jednostce lekcyjnej. Potrzebne są więc jeszcze odpowiednie cechy osobowości nauczyciela organizatora procesu kształcenia i rozeznanie w poziomie wiedzy i umiejętności uczniów. Aktywizowanie uczniów wymaga zatem odpowiednich kompetencji nauczycieli. Samodzielne myślenie i aktywizacja są zjawiskami od siebie uzależnionymi, wzajemnie się warunkują. Można wyróżnić dwa zasadnicze etapy: pierwszy, gdy przeważa aktywizowanie ucznia przez nauczyciela - aktywizacja bezpośrednia, prowadząca do rozwoju myślenia samodzielnego; drugi okres, w którym myślenie samodzielne ucznia powoduje jego aktywność [W. Okoń]. W pierwszym z nich jednostka jest aktywna przeważnie $\mathrm{z}$ pomocą bodźców z zewnątrz, w drugim pod wpływem impulsów własnych - wewnętrznych. Wywołują je wzrost wiedzy i myślenia logicznego u nauczanych oraz nawyki poprawnego posługiwania się różnymi typami operacji myślowych, jak abstrahowanie, uogólnianie, analiza, synteza, analogia. 
3. Kształcenie ogólnotechniczne warunkiem całościowego rozwoju ucznia

W kształceniu skoncentrowanym na uczniu uwzględnia się zazwyczaj motywacje uczniów (tj. ich zamiłowania, zainteresowania, zdobyte doświadczenia), istotę procesu uczenia się ( $\mathrm{tj}$. psychologiczne mechanizmy umożliwiające uczenie się, a nie treści uczenia się) oraz fakt, iż uczniowie mają różne tempo pracy i różne zainteresowania. Istotne jest zatem znaczenie indywidualizacji kształcenia. Jeszcze inne podejście polegać może na przeciwstawieniu „metod aktywnych” polegających na tym, że uczeń samodzielnie szuka potrzebnych mu informacji, uczy się dzięki własnym odkryciom i twórczości, metodom, w których wykorzystuje się materiały przygotowane przez nauczyciela $\mathrm{i}$ prezentowane zgodnie $\mathrm{z}$ jego uznaniem. W różnych przedmiotach szkolnych aktywizacja uczniów sprzyja rozwojowi różnorodnych umiejętności, głównie intelektualnych. W edukacji ogólnotechnicznej wykonywanie zadań praktycznych pozwala na kształtowanie umiejętności manualno - motorycznych, koordynacji wzrokowo - ruchowej, sprawności i nawyków, które są dopełnieniem całościowego rozwoju młodego człowieka. Sprawne posługiwanie się prostymi narzędziami, typu nożyczki, nóż introligatorski, kolec, ćwiczy rączkę dziecka, które w dojrzałym wieku będzie być może obsługiwało precyzyjne urządzenia techniczne. Zdobyta umiejętność praktyczna, dzięki transferowi, $\mathrm{z}$ pewnością pozwoli rozwinąć lepiej umiejętności zawodowe, osiągnąć sukces w dorosłym życiu. Zadania wytwórcze, montażowe, konserwacyjno eksploatacyjne są niezwykle kształcące w zakresie bezpiecznego, racjonalnego korzystania z osiągnięć techniki w gospodarstwie domowym. Proces kształcenia technicznego będzie miał największą wartość wówczas, gdy cechować go będzie twórcze techniczne myślenie i działanie. T. Nowacki, analizując takie myślenie i działanie, wymienił dziesięć etapów powstawania dzieła technicznego: uświadamianie potrzeby wynalazku, sformułowanie zasadniczego zadania, idei poszukiwanego urządzenia, uściślenie zadania, poszukiwanie możliwości rozwiązania, opracowanie głównej zasady poszukiwanego urządzenia, przekształcenie zasady $\mathrm{w}$ schemat, rozwinięcie schematu, opracowanie technologiczne, sprawdzenie teoretyczne opracowania technicznego i technologicznego, wykonanie prototypu i sprawdzenie praktyczne na prototypie
[J. Wilsz, 2003]. Człowiek jest istotą poszukującą optymalnych warunków do życia, dążącą do rozumienia i opanowania techniki, zmierzającą do samopoznania, że edukacja techniczna człowieka stanowi konieczność rozwojową rodzaju ludzkiego. Idea kształcenia technicznego, pojmowanego jako ciągłe poznawanie odkryć nauki i techniki, jest obecna we wszystkich wielkich systemach filozofii człowieka. Nadrzędnym celem edukacji ogólnotechnicznej powinno być wspomaganie rozwoju wychowanków w kierunku osobowości aktywnej, czynnie zaangażowanej w zjawiska życia społecznego, otwartej intelektualnie i ciągle doskonalącej się. Edukacja ogólnotechniczna powinna przyczyniać się między innymi do uświadomienia młodemu człowiekowi sensu i potrzeby kształcenia zawodowego. Poprzez ten rodzaj kształcenia młody człowiek powinien mieć ułatwiony wybór zawodu oraz prawidłowe rozpoczynanie przygotowania się do kwalifikowanej pracy zawodowej przez kształcenie zawodowe.

\section{Zakończenie}

W roku 2009 przeprowadzono badania pedagogiczne wśród nauczycieli szkół gimnazjalnych na temat aktywizowania uczniów na lekcjach techniki. Celem ich było ustalenie najważniejszych czynników wyzwalających zaangażowanie ucznia w działaniu praktyczno technicznym. Analiza zebranych za pomocą kwestionariusza ankiety opinii pozwala stwierdzić, że poziom wiedzy i przygotowanie nauczycieli do aktywizacji jest dość dobre. $\mathrm{Z}$ ankiety wynika, że według przebadanych nauczycieli duża liczba uczniów w klasie utrudnia aktywizację. Lepiej pracuje się w małych grupach, indywidualizując nauczanie, co wydaje się dość oczywiste. Najbardziej pożądanymi u nauczyciela są zdolności komunikacyjne, wiedza merytoryczna, predyspozycje pedagogiczno-psychologiczne, kompetencje dydaktyczne i życzliwa postawa. Najważniejsze warunki jakie należy zapewnić uczniom w działaniu praktyczno - technicznym, aby optymalizować proces kształcenia uzyskując zaangażowanie i rozwój intelektualny oraz sensoryczno - motoryczny to:

- stosować metody stymulujące twórcze myślenie, takie jak np.: dyskusja, rozwiązywanie problemów technicznych, metoda projektów $\mathrm{w}$ początkowym etapie działania praktycznego, 
- zapewnić pracę ucznia na stanowisku urządzonym wzorowo, wyposażonym w niezbędne narzędzia i urządzenia techniczne,

- wykonywać zadania i prace techniczne użytkowe, aby uczeń mógł wykorzystać nabyte umiejętności w życiu codziennym,

- stosować pozytywne wzmocnienia motywując do współzawodnictwa, zastosowania ulepszeń, racjonalizacji pracy, podkreślając walory użyteczne i praktyczne wykonywanych prac, przekazanie wytworów technicznych najbliższym itp.,

- dążyć do organizacji działania w małych grupach, wspierać samodzielność wymagać poprawnego i dokładnego działania.

Aktywizacja ucznia w procesie dydaktyczno wychowawczym jest podstawą pełnego rozwoju osobowości , stymuluje rozwój intelektu, koordynacji wzrokowo - ruchowej, sensory ki, pozwala na odkrycie nowych pokładów energii i zasobów wiedzy, a także przyczynia się do przełamywania nieśmiałości.

\section{Literatura:}

(1) Okoń W., Nowy słownik pedagogiczny, PWN, Warszawa 2004

(2) Mastalerz E., Gałązka E.: Inspiracje do aktywizującej uczniów edukacji ogólnotechnicznej, Wydawnictwo Naukowe AP, seria: NOWOCZESNA SZKOŁA, Kraków, 2006, s.238, ISBN 83-7271-398-7

(3) Wilsz J., Aktywizowanie uczniów w procesie kształcenia technicznego, [w:] Edukacja techniczna i informatyczna: poglady, wyzwania $i$ możliwości, red. M. Kajdasz - Aouil, A. Michalski, Bydgoszcz 2003

(4) Ziętkiwicz K. M., Jak aktywizować uczniów. „Burza mózgów” $i$ inne techniki $w$ edukacji, Poznań 2000

Elżbieta Mastalerz dr

Uniwersytet Pedagogiczny

Kraków ul. Podchorążych 2

30-084 Kraków

e-mail: elzbietamastalerz@wp.pl 